\title{
LAND-USE CHANGES AND THEIR RELATIONSHIPS TO SELECTED LANDSCAPE PARAMETERS IN THREE CADASTRAL AREAS IN MORAVIA (CZECH REPUBLIC)
}

\author{
Zdeněk OPRŠAL, Bořivoj ŠARAPATKA, Petr KLADIVO
}

\begin{abstract}
The analysis of changes in landscape use and the related significance of some natural factors is examined in this paper, using three municipal cadastral areas in Moravia, Czech Republic. The relationships between changes in the use of the rural landscape and natural conditions were analyzed with the use of GIS tools and methods of canonical correspondence analysis (CCA). The CCA results showed a correlation between the selected natural factors and landscape changes, with the most significant factors being those of slope and altitude. The CCA models exhibited varying reliability in accounting for the extent of landscape changes related to topographical diversity of the territories. Natural conditions were more influential in periods with lower change dynamics and at the same time in areas with higher topographic heterogeneity. Although the results of the statistical analyses confirmed the significance of natural factors, only a part of land use changes could be explained by their influence. Socio-economic factors are apparently the main forces affecting landscape character and change .
\end{abstract}

\section{Shrnutí}

\section{Změny ve využití krajiny a jejich vztah k vybraným přírodním faktorưm na příkladu tří katastrálních území na Moravě}

Článek se soustřed’uje na analýzu změn využití krajiny a význam vybraných př́rodních faktorů na př́kladu tři katastrálních území obcív České republice. Vztah mezi změnami ve využití venkovské krajiny a př́rodními podmínkami byl analyzován pomocí nástrojů GIS a metod kanonické korespondenční analýzy (CCA). Výsledky CCA prokázaly korelaci vybraných př́rodních faktorů a krajinných změn, pričemž nejvýrazněji se projevovaly faktory sklonu svahu a nadmořské výšky. CCA modely vykazovaly rozdílnou spolehlivost $v$ závislosti na rozsahu krajinných změn a topografické různorodosti území. Př́rodní podminky se ve větší míre uplatňovaly v obdobích s nižši dynamikou změn a zároveň v oblastech s vyšší topografickou heterogenitou krajiny. Ačkoliv výsledky statistických analýz potvrdily význam př́rodních faktorů, bylo jimi možné vysuětlit jen část celkových změn využití krajiny. Je zrejmé, že socioekonomické faktory jsou hlavními silami, které mají vliv na charakter krajiny.

Keywords: Land-use change, rural landscape, environmental factors, Canonical Correspondence Analysis, Moravia, Czech Republic

\section{Introduction}

Landscape changes are greatly influenced by socioeconomic driving forces and by natural conditions. While the socio-economic factors are distinctly diverse and locality-specific, the natural conditions (e.g. slope gradient, altitude, soil quality etc.) are not dependent on changes in political systems or human society. The relationship between landscape changes and environmental factors is a theme which has not been given as much attention in former Eastern Block countries as it has received in Western Europe (e.g. Hietel et al., 2005). The landscape of these countries has undergone dramatic changes in many respects (Bičík and Štěpánek, 1994; Lipský, 1995; Lorincz and Balazs, 2002). Given the existence of unique historical maps of Central Europe (Bender, 2009), these changes in landscape structure were described in a number of local and regional studies. However, landscapeecology studies usually focus on the description of the chronological and spatial development of the landscape structure at various scales (e.g. Machar and Servus, 2010, Demek et al., 2008, Cebecauerová, 2007), or they may analyze socio-economic factors (as driving forces) (Bičík et al., 2001; Lowicky, 2008). The role 
of environmental influences on landscape dynamics is generally given less attention. One of the aims of this article is to contribute to the understanding of the importance of specific environmental factors in the dynamics of landscape change in Central Europe using an example of three case studies in Moravia.

This paper focuses on the role of natural factors in rural landscape changes. The areas chosen for research represent various natural conditions typical of the Czech Republic. Two time periods were chosen (1938-1984 and 1984-2009), which encompass periods of significant change in the Czech society and landscape. The first period covers landscape changes following the introduction of socialism in 1948 and the subsequent period of agricultural collectivization. Changes of agricultural management methods were exhibited particularly in a marked waning of grasslands, especially in fertile agricultural areas, and in the distinctly increasing average size of fields (Šarapatka and Štěrba, 1998). The simplification of landscape structure and intensification of farming methods resulted in an overall degradation of the rural landscape. The second, shorter period, represents the transformation from socialist management to a market economy and the return to private forms of land and landscape management after 1989. These recent changes primarily encompass reduction in the acreage of arable land and extensification of farming in highland and upland regions, where the acreage of permanent grassland increased (Bičík et al., 2001).

\section{The relationship between landscape development and environmental conditions}

Changes in the landscape cover are also determined by a complex set of interactions between environmental and socio-economic factors. Knowledge of the dynamics of change in the landscape can contribute to an understanding of the historical development of land use and serve as a basic guide in predicting future changes in the landscape cover (Veldkamp and Lambin, 2001). This knowledge is important in establishing the sustainable management of the landscape and protection of basic landscape functions.

The dependence of the development of landscape changes on natural conditions has been the focus of several studies. However, their conclusions are not definite and it is difficult to generalize them due to the limited size of the areas studied. For example, the studies by Pan et al., 1999; Chen et al., 2001; Fu et al., 2006, all demonstrated a close relationship between natural factors and land use changes. Other studies, however, (e.g. Schneider and Pontius, 2001; Hietel et al., 2004; Hietel et al., 2005) indicated that land use changes had only a slight correlated dependence on natural conditions. The relationship between natural conditions and changes in land cover is, apart from natural factors, to some varying extent influenced by human activity, which can modify or eliminate the influence of the natural environment.

Research has also shown that the intensity of dependence on natural conditions may also be influenced by the landscape type, or rather by landscape topography. Changes in the spatial structure of landscape in highland regions are, according to del Barria et al. (1997), significantly more dependent on natural factors than in intensively-farmed agricultural regions. Schneider and Pontius (2001), who studied intensively-used landscapes, indicated lower significance of environmental factors on land use changes use due to lower topographic diversity. On the other hand, according to Simpson et al. (2001), greater geomorphological diversity of landscape has a significant influence on the dynamics of land use change.

Factors such as land gradient, altitude and soil type influence the intensity of agricultural production. In areas characterized by steeper gradients, at higher altitudes and with less fertile soils, agricultural production results in lower yields due to the unfavourable natural conditions. Poor access for agricultural machinery may also play a role. Farming is concentrated in more fertile areas, whereas in agriculturally marginal areas there is a transition to less intensive forms of land use. Changes in land cover also relate to these factors - as confirmed in a study by Hietel et al. (2004) which confirmed a transition from arable land to grassland in areas of higher altitudes, with steeper gradient and worse soil quality. A similar conclusion was published by Fu et al. (2006), explaining the transformation from arable land to forest or grassland occurred especially on low-quality soils typified by steep slopes and damaged by erosion. On the other hand, newly-cultivated land emerged especially on fertile soils and on gently sloping terrains. Chen et al. (2001) confirmed the influence of slope and claimed difficult access as the main reason for gradual extensification of farming in areas with a steeper slope. On the other hand, they suggest that exposure of slope was not a significant factor in land-use changes (Chen et al. (2001). Finally, Simpson et al. (1994) and Pan et al. (1999) also studied geomorphological characteristics of land and pointed to a transition to less intensive forms of land use (from pasture to abandoned land, and from abandoned land to forest) on sites more difficult to work, for example on moraines, or in areas of higher altitudes. This study confirmed the findings of the above-mentioned researchers: namely that gradient, 
altitude, and soil characteristics proved to be the main determining factors in natural land cover changes, whereas slope aspect had no distinct influence.

Furthermore, this study shows that only a relatively small proportion of changes in landscape cover can be explained by environmental changes, especially in periods of great dynamic changes. The explanation can rely on the exclusion of several other environmental factors, but also on the fundamental influence of socio-economic factors. Subsequent research including selected socio-economic factors (Hietel et al., 2005) confirmed that land use changes result from the combined influence of environmental and socioeconomic factors, which are in mutual interaction.

\section{Material and methods}

\subsection{Study area}

Three case study areas in the Czech Republic were chosen for the purposes of this study: the rural districts of Archlebov, Branná and Rychtářov (Fig. 1). Case selection criteria reflected an effort to represent the diversity of natural conditions. The chosen locations vary in character, from the most agriculturally fertile district of Archlebov, through the less-favourable upland landscape of Rychtářov, to the upland/highland character of the Branná district.

The Archlebov district has an area of $13.32 \mathrm{~km}^{2}$ and is located in an old residential area of characteristically fertile intensively-farmed chernozem developed on loess. Arable land dominates in this area, partly situated on agrarian terraces, with no pasture land whatsoever. The northern section of higher elevation has been traditionally used for orchards and vineyards. The altitude range of this area is 200 $415 \mathrm{~m}$, with most farmland occurring at altitudes up to $350 \mathrm{~m}$. Average annual temperature is $8-9^{\circ} \mathrm{C}$, average rainfall is $500-550 \mathrm{~mm}$.

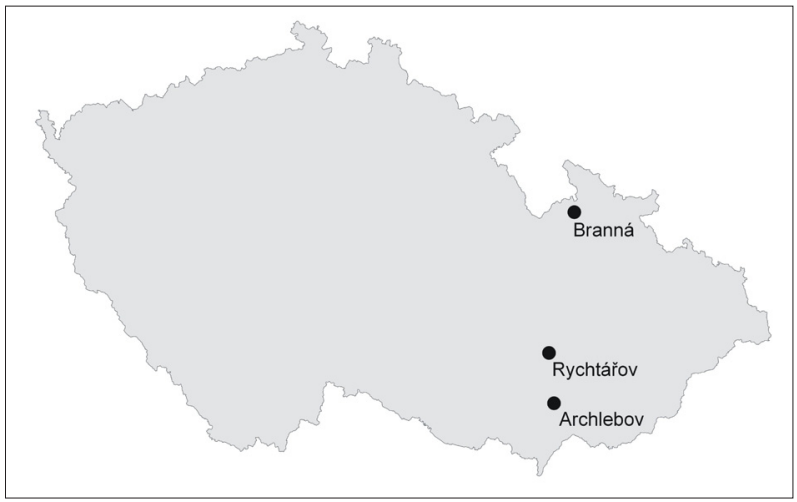

Fig. 1: Location of three study areas of Archlebov, Branná and Rychtárov in the Czech Republic Source: The map was created by the authors with the use of ArcGIS 9.2, 2011
The Rychtářov district has an area of $11.52 \mathrm{~km}^{2}$. According to historical records it was originally established as a forest plantation but soon acquired the character of farm land. Both arable land and permanent grasslands occur in the district. The landscape is of upland character with altitudes ranging from 309 $487 \mathrm{~m}$, the mean annual temperature is $7-8^{\circ} \mathrm{C}$ with a mean total precipitation amount is $600-650 \mathrm{~mm}$. The dominant soil types are cambisols and brown earths. The district of Rychtářov was threatened with demise during WWII because the German occupying authorities decided to evict the predominantly Czech inhabitants and turn the area into a military training ground. After the war, some of the residents returned to their devastated homes, but their number has never resumed the pre-war level.

The Branná district in the Jeseník highland region has an area of $14.56 \mathrm{~km}^{2}$. A significant role in its settlement was played by the mining of precious metals, although in the $19^{\text {th }}$ and $20^{\text {th }}$ centuries the area was predominantly of agricultural character. The region's population underwent a dramatic change after WWII. Branná lies in the former Sudetenland, which was occupied mainly by people of German nationality before WWII. After the war, these inhabitants were displaced from Czechoslovakia and partial reoccupation occured with people of Czech nationality from other parts of the country. Apart from essential economic and social consequences, these changes also affected the use of the landscape. Arable land gradually disappeared from the region and was replaced by pastures, which now dominate the use of agricultural land in this highland region. Natural conditions of the area are of sub-mountainous/mountainous character altitude 542-905 m, mean annual temperature 6-7 ${ }^{\circ} \mathrm{C}$, mean annual precipitation amount $800-1000 \mathrm{~mm}$. The landscape features a varied geological composition, with the dominant soil type being cambisols and their modifications.

\subsection{Land-use data}

For this study, we used a series of historical and contemporary aerial photographs of all three areas of land taken in the years 1937, 1984 and 2009. These years chosen made it possible to observe basic land use changes in two periods: 1938-1984 and 1984-2009. The first period includes changes in landscape structure and land use after 1948, the second period covers the period of agricultural transformation after 1989. The historical aerial photos from 1938 and 1984 lacked a valid system of coordinates. Therefore, they were orthorectified using the programme Leica Photogrammetry Suite (Leica Geosystems, 2006). The interpretation of the historical aerial photos was based on the analysis of interpretational marks of individual properties (Feranec 
and Otahel, 2001) with a simultaneous use of archive data and cadastral maps. On the basis of the CORINE Land Cover classification (Bossard et al., 2000), the landscape cover was divided into five basic categories: forest, arable land, grassland, water body and building. Using the ArcGIS 9.2 programme, the map data were manually transformed into digital topographic maps..

\subsection{Environmental attribute data}

The analysis primarily included environmental variables, representing natural physical attributes of the landscape, and also structural variables expressing the anthropogenic impact on the landscape structure (Hietel et al., 2004). The analyzed environmental factors included gradient, slope aspect, altitude, soil type and form of bedrock. Structural variables were represented by distance of the plot of land from the district centre and by the plot size. A map of gradient and slope orientation was obtained from a digital model of terrain on a scale 1:10 000 with the use of a spatial operation in the programme 3D Analyst ArcGIS 9.3. Average altitude of plots was taken from the contour lines on a scale 1:10 000, provided by the Czech Office for Surveying, Mapping and Cadastre. Raster land maps of the Czech Republic at 1:50 000 were orthorectified and digitized. Categories were maintained according to the national Taxonomic Soil Classification System (Němeček et al., 2011). A total of 8 soil types were defined: chernozems, haplic luvisols, fluvisols, albic luvisols, cambisols, regosols, stagnosols and gleysols.

With regard to the varying natural and geographic conditions, individual soil types usually developed only in certain areas of interest. Geological maps of the Czech Republic 1:50 000 were processed in the same way as the land maps. A total of 10 types of bedrock were identified: fluvial sediment, deluvial sediment, loess, schist, marble, gneiss, phyllite, quartzite, amphibolite and greywacke. In terms of geological bedrock, the individual areas of interest varied, too. The distance of the plots of land from the centre of the village represents accessibility; this variable, however, does not consider topographic conditions and the road network.

\subsection{Spatial and multivariate analysis}

In order to determine overall landscape changes and to identify the relationship between the main transformation processes in the landscape and natural conditions, a spatial analysis was carried out by overlapping digital layers for the chosen years within the geographic information system. First of all, by combining three digital land-use layers (for 1939, 1984 and 2009), layers were produced to represent the landscape cover transformation in the two observed periods (1939-1984 and 19842009). Subsequently, these newly-created layers were combined with the layers of geological and soil conditions. For all polygons representing the individual types of landscape development, calculations were made using a spatial operation of gradient, slope orientation and average altitude values. The variable of distance was set as a distance of the plot centre from the village centre. With regard to changes in the built-up area of individual villages, a distance from the church was used, as the church usually represents the village centre and its location remains unchanged over the years. The results in the form of an attribute table served as the basis for the partial analysis of landscape changes and canonical correspondence analysis.

By combining the layers for land use in various time periods, a combination of individual types emerged. These were the named landscape development types. The development types represented either the transformation from one land use form to another (e.g. arable land - permanent grassland), or the continuation of the same land use (e.g. land which is forested in both time periods). The resulting number of landscape development types was, however, too large. Therefore, it was reduced by combining them into six main types relating to primary processes occurring in the landscape. The processes were identified and described in the context of the European landscapes in the EEA report Land Accounts for Europe 1990-2000, specifically for the region of Central Europe e.g. in a study by Feranec et al., 2000. The following significant processes of landscape change were defined for our study areas:

- Urbanization: increase in the area of urban land use categories (any transformation to urban form);

- Intensification of agricultural production: increase in the acreage of arable land, vineyards and orchards;

- Extensification of agricultural production: shrinking arable land and other categories of intensive agricultural production in favour of extensive production (except for the transformation of agricultural land to forest);

- Forestation: increasing area of forested land categories;

- Deforestation: decreasing area of all forest categories; and

- Construction of water bodies: due to minimum occurrence, this category was omitted from the analysis.

Canonical Correspondence Analysis (CCA) was used to evaluate the relationships between the identified processes and the selected environmental and structural variables. The reliability of the resulting model, e.g. isolated axes and significance of relationships, was tested using the Monte Carlo permutation test. 


\section{Results}

\subsection{General trends in land-use changes}

The results of the partial analysis indicated that the individual plots of land differed in the nature and intensity of land-use changes (Tab. 1).

In the period 1938-1984, the Branná district was by far the most dynamic area (see Fig. 2), which has to do with its historical development (removal of the original German population) and the submountainous/mountainous character of the territory. In this period, as much as $60.4 \%$ of the land underwent transformation. In terms of their extent, the most significant processes were extensification (especially the transformation of arable land into grassland: $31.3 \%$ of the area) and forestation (28.5\% of the area). Both processes concerned areas with a steep gradient (11.5\% extensification; $14.0 \%$ forestation) and with the relatively high elevation (average $720 \mathrm{~m}$ a.s.l. in both cases). Other recorded processes (urbanization, intensification, deforestation) were marginal in extent, while intensification of agricultural production took place mainly on fluvial and deluvial soils at a more favourable altitude (640 $\mathrm{m}$ a.s.l.) and near to the village. In the following period 1984-2009, the areas were much more stable in terms of landscape changes, with only $12.2 \%$ of land being affected by changes. As with the previous time period, the processes of land use extensification (8.6\% of land) and forestation (3.1\% of land) continued. The other monitored processes showed only low levels of intensity.

In the case of Rychtářov, the period 1938-1984 was by contrast the most stable period, as only about $1 \%$ of the area (14 ha) underwent transformation, of which 3.5 ha was increased size of water surface and the same area (3.5 ha) was built up. Nearly 3 ha were forested; changes in extensification and intensification were rather insignificant. In the

\begin{tabular}{|c|c|c|c|c|c|c|c|c|c|c|c|c|}
\hline \multirow{3}{*}{$\begin{array}{l}\text { type of } \\
\text { process }\end{array}$} & \multicolumn{4}{|c|}{ Archlebov } & \multicolumn{4}{|c|}{ Rychtářov } & \multicolumn{4}{|c|}{ Branná } \\
\hline & \multicolumn{2}{|c|}{ period 1938-1984 } & \multicolumn{2}{|c|}{ period 1984-2009 } & \multicolumn{2}{|c|}{ period 1938-1984 } & \multicolumn{2}{|c|}{ period 1984-2009 } & \multicolumn{2}{|c|}{ period 1938-1984 } & \multicolumn{2}{|c|}{ period 1984-2009 } \\
\hline & $\begin{array}{l}\text { area } \\
\text { (ha) }\end{array}$ & $\begin{array}{c}\text { share } \\
(\%)\end{array}$ & $\begin{array}{l}\text { area } \\
\text { (ha) }\end{array}$ & $\begin{array}{c}\text { share } \\
(\%)\end{array}$ & $\begin{array}{l}\text { area } \\
\text { (ha) }\end{array}$ & $\begin{array}{c}\text { share } \\
(\%)\end{array}$ & $\begin{array}{l}\text { area } \\
\text { (ha) }\end{array}$ & $\begin{array}{c}\text { share } \\
(\%)\end{array}$ & $\begin{array}{l}\text { area } \\
\text { (ha) }\end{array}$ & $\begin{array}{c}\text { share } \\
(\%)\end{array}$ & $\begin{array}{l}\text { area } \\
\text { (ha) }\end{array}$ & $\begin{array}{c}\text { share } \\
(\%)\end{array}$ \\
\hline no change & $1,253.53$ & 94.4 & $1,287.81$ & 96.7 & $1,139.09$ & 99.09 & $1,093.69$ & 94.86 & 576.89 & 39.6 & $1,278.41$ & 87.8 \\
\hline urbanization & 18.35 & 1.4 & 3.05 & 0.2 & 3.41 & 0.30 & 3.75 & 0.33 & 3.28 & 0.2 & 1.99 & 0.1 \\
\hline intensification & 4.17 & 0.3 & 10.47 & 0.8 & 0.59 & 0.05 & 0.72 & 0.06 & 1.81 & 0.1 & 0.00 & 0.0 \\
\hline extensification & 23.50 & 1.8 & 11.96 & 0.9 & 2.47 & 0.21 & 27.94 & 2.42 & 455.27 & 31.3 & 126.49 & 8.7 \\
\hline forestation & 27.17 & 2.0 & 11.51 & 0.9 & 2.83 & 0.25 & 26.57 & 2.30 & 415.18 & 28.5 & 44.58 & 3.1 \\
\hline deforestation & 1.69 & 0.1 & 7.20 & 0.5 & 1.16 & 0.10 & 0.33 & 0.03 & 3.56 & 0.2 & 4.53 & 0.3 \\
\hline
\end{tabular}

Tab. 1: Area size (ha) and share (\%) of land-use changes in the Archlebov, Rychtarov and Branná study areas Source: authors

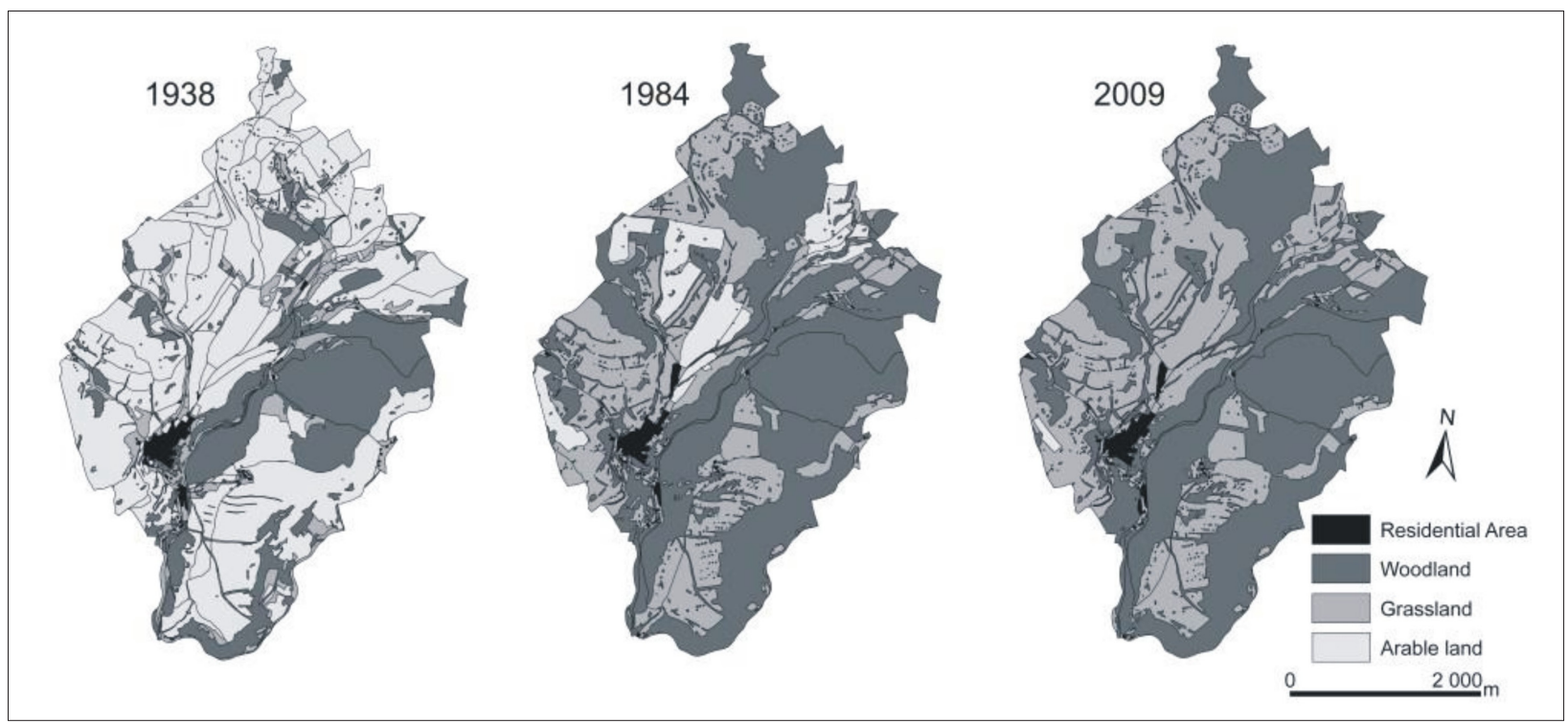

Fig. 2. Land-use patterns of the Branná study area in 1938, 1984 and 2009 Source: Maps were created by the authors with the use of ArcGIS 9.2, 2011 
following period 1984-2009, landscape transformation intensified (approximately $5 \%$ of this area, representing almost 60 ha). Forestation was the most notable process, covering predominantly cambisols on steeper gradients (av. 8\%). At the same time, extensification appeared as the conversion of crop fields to pasture land; this process was connected with the occurrence of cambisols and luvisols on greywackes.

The area of Archlebov can be characterized, in terms of land cover transformation and its dynamics, as relatively stable, as this only affected less than $6 \%$ of the area in the first time period 1938-1984. During that time, the most significant of all the monitored processes were those of extensification and forestation relating to steeper gradient of slopes (7-9\%). In contrast to Rychtárov and Branná, the process of urbanisation in Archlebov was relatively significant (1.4\% of the area, i.e. 18 ha in total). Intensification was also relatively distinct, occurring on $4.17 \%$ of the area. The intensity of transformation processes between 1984 and 2009 was at a similar level as in the previous period. Intensification mainly involved fluvisols while a part of the territory with unfavourable gradients (av. 12.5\%) underwent the opposite process of extensification.

\subsection{Canonical Correspondence Analysis of relationship between land cover changes and environmental variables}

CCA enables the researcher to identify the relationships between land cover changes and environmental variables. Due to varying natural conditions, the analysis was carried out separately for each monitored territory and in two time periods; altogether, six CCA analyses were carried out. The Monte Carlo test provided the significance of the monitored environmental variables. The relationship of individual characteristics to the monitored processes of landscape changes are visualised in ordination graphs. Relationships of extracted axes to selected variables are given in the table of correlation coefficients (Tab. 2), which also shows the significance of individual variables.

The CCA results showed that only a limited proportion of landscape changes were dependent on natural factors. The effectiveness of models differed in this respect - it was lowest in the case of Branná in the first period of 1938-1984 when it only explained $3 \%$ of the original information. In the second period - 1984-2009, this model could explain $11.2 \%$ of the variance in the first two canonical variables. The most successful models were those of Rychtářov (15.9\% for 1938-1984 and $16.7 \%$ for 1984-2009) and Archlebov (32.6\% for 1938-1984); these values are within the range found by Hietel et al. (2004).

It is obvious from the level of CCA model success that the dependence of landscape changes on environmental characteristics is to a certain extent determined by the overall dynamics and character of landscape changes. The lowest values in the case of Branná relate to the fundamental transformation of the landscape, which was largely dominated by socioeconomic processes (the post-war eviction of German residents and the related attempt to re-populate the area affected the use of the area quite notably) while the environmental characteristics, despite their relatively high diversity, played just a marginal role. The relatively low success of the Archlebov model in 1984-2009 probably relates to the character of changes - in this period, the agrarian terraces were built. Environmental variables played a significantly greater role in the monitored landscaping processes in areas with a relatively low overall dynamics of change and also in areas with greater topographical diversity (Rychtářov in both periods and Archlebov in the first period). However, the relatively low success rate of some models does not mean a failure of the CCA analysis but rather points out the limited ability

\begin{tabular}{|c|c|c|c|c|c|c|c|c|c|c|c|c|}
\hline & \multicolumn{4}{|c|}{ Archlebov } & \multicolumn{4}{|c|}{ Rychtářov } & \multicolumn{4}{|c|}{ Branná } \\
\hline & \multicolumn{2}{|c|}{ period 1938-1984 } & \multicolumn{2}{|c|}{ period 1984-2009 } & \multicolumn{2}{|c|}{ period 1938-1984 } & \multicolumn{2}{|c|}{ period 1984-2009 } & \multicolumn{2}{|c|}{ period 1938-1984 } & \multicolumn{2}{|c|}{ period 1984-2009 } \\
\hline & Axis I & Axis II & Axis I & Axis II & Axis I & Axis II & Axis I & Axis II & Axis I & Axis II & Axis I & Axis II \\
\hline area & 0.2474 & -0.0150 & 0.2475 & -0.0151 & 0.0878 & 0.3049 & 0.0442 & -0.2262 & 0.7739 & 0.0130 & 0.6162 & 0.0669 \\
\hline elevation & -0.8883 & 0.2686 & 0.7321 & 0.4125 & -0.6418 & -0.0753 & 0.6433 & -0.2219 & 0.1429 & -0.7645 & 0.3422 & -0.4592 \\
\hline slope & -0.4711 & 0.3103 & 0.7616 & -0.3623 & 0.0332 & -0.5846 & -0.3944 & 0.0378 & -0.4134 & -0.2884 & -0.5960 & 0.0737 \\
\hline aspect & -0.0347 & 0.0046 & 0.1679 & -0.0429 & 0.4375 & -0.1837 & -0.4594 & -0.4529 & -0.0748 & 0.0635 & 0.2118 & -0.4152 \\
\hline distance & 0.8422 & 0.4906 & -0.4453 & -0.5483 & 0.3357 & 0.6507 & 0.2201 & 0.4861 & -0.1518 & 0.1906 & -0.4962 & 0.0734 \\
\hline
\end{tabular}

Tab. 2. Intraset correlations between environmental variables and the first and second RDA axes

Source: Statistical evaluation in Canoco for Windows, 2011 
of the environmental factors alone to explain changes in the landscape. The dynamics of landscape change undoubtedly depends also on the socio-economic factors. Considering their nature and variability, the inclusion of these factors in the CCA analysis is significantly limited.

The influence of environmental variables on the studied processes of landscape development is documented in ordination graphs from the canonical correspondence analysis (Figs. 3-5). The arrow length indicates the correlation of a given variable with the extracted ordination axis. Points represent the individual soil and rock types and the transformation processes. Their position indicates a relationship to the respective variable. In the case of Branná (19381984), the position of points pedo 1 and geo 7 (fluvisol, fluvial sediment) is not surprising in the upper left part of the diagram for the characteristically low altitude, whose vector points in the opposite direction. The relationship between the urbanization process and lower-lying land in the Branná cadaster is also logical. The most numerous instances of land transformation through extensification and forestation characteristically relate to higher altitudes with steeper terrains and larger areas.

The significance of individual environmental variables varies within the studied areas, but we can generally state that, of all explored environmental variables, slope gradient has the greatest effect. This variable is significantly evident in both the transfer to more intensive land use forms (relating to gently sloping terrains) and to extensification (forestation and other extensification processes on steep terrains which are difficult to farm). Altitude is also a notable environmental factor demonstrated in all areas of interest; its significance was particularly greater in territories more diverse in terms of elevation.

Other environmental variables are represented locally. For example the acreage of individual elementary plots is statistically important in Branná where, especially in the first time period studied, larger-size plots were significantly transformed. The influence of slope orientation and distance from the village is less demonstrable. The explanation of the relationship of soil and bedrock environment to landscape changes is rather debatable due to the remarkable difference in the proportion of types represented in the monitored areas. Nevertheless, there is quite a strong relationship between less fertile cambisols and luvisols and the transition to extensive farming.

The presented models did not consider stable areas where landscape use remained unchanged in consequential time periods; their inclusion would have probably changed the success rate in the individual models. Besides topographic characteristics and intensity of landscape processes, the changing success rate of the models is affected by the selection of individual data entering the CCA (ter Braak and Šmilauer, 2002). The basic environmental variables (altitude, gradient, aspect) set via GIS are included in

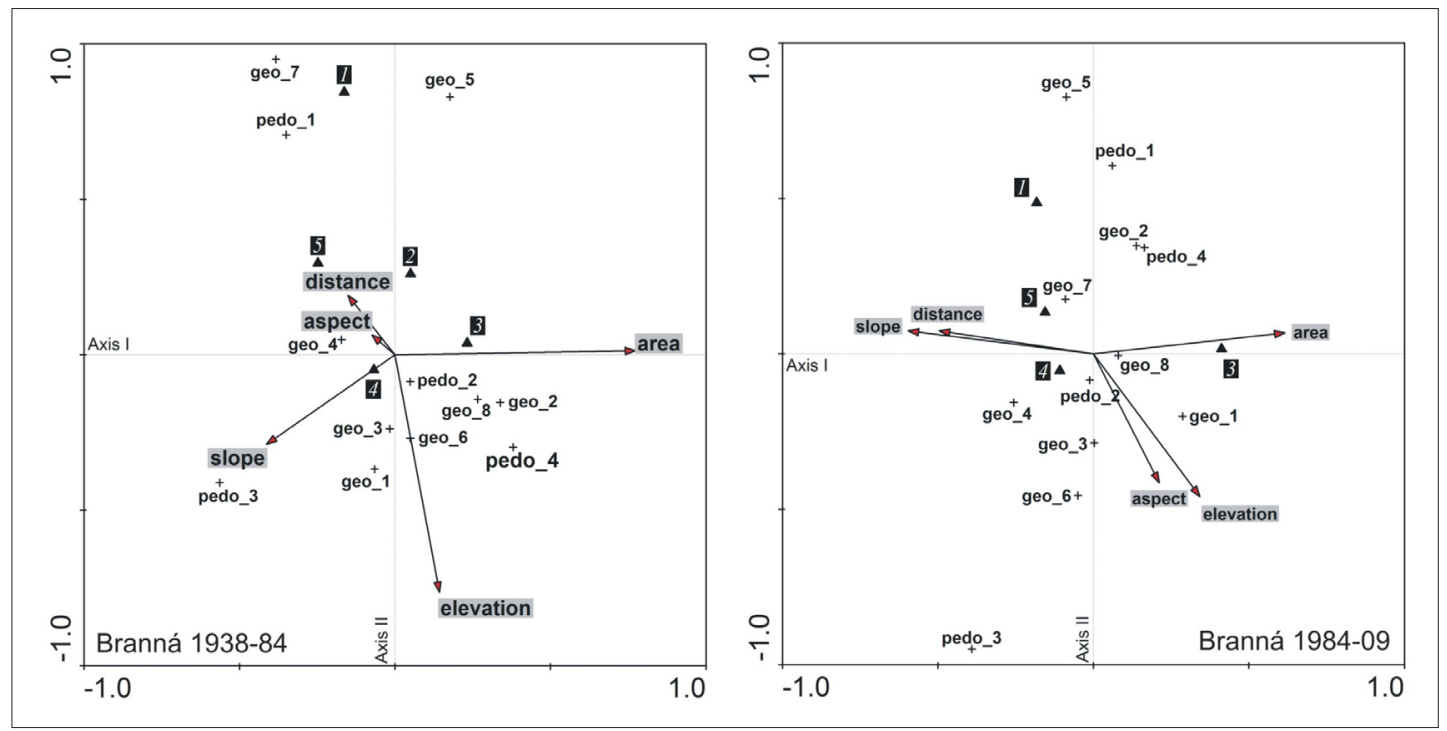

Fig. 3. CCA ordination of land cover transitions in two time periods (1938-1984 and 1984-2009) in the study area of Branná

Codes used in figs. 3-5: 1 - urbanization, 2 - intensification of agricultural production, 3 - extensification of agricultural production, 4 - forestation, 5 - deforestation; geo_1 - schist, geo_2 - marble, geo_3 - gneiss, geo4 phyllite, geo_5 - quartzite, geo_6-amphibolite, geo_7-fluvial sediments, geo_s-deluvial sediments, geo_9-loess, geo_10 - flysch, geo 11 - greywackes; pedo_1 - fluvisol, pedo_2 - cambisol, pedo_3 - stagnosol, pedo_4-regosol, pedo_5 - chernozem, pedo_6 - haplic? luvisol, pedo_7-albic luvisol, pedo_8-gleysol 

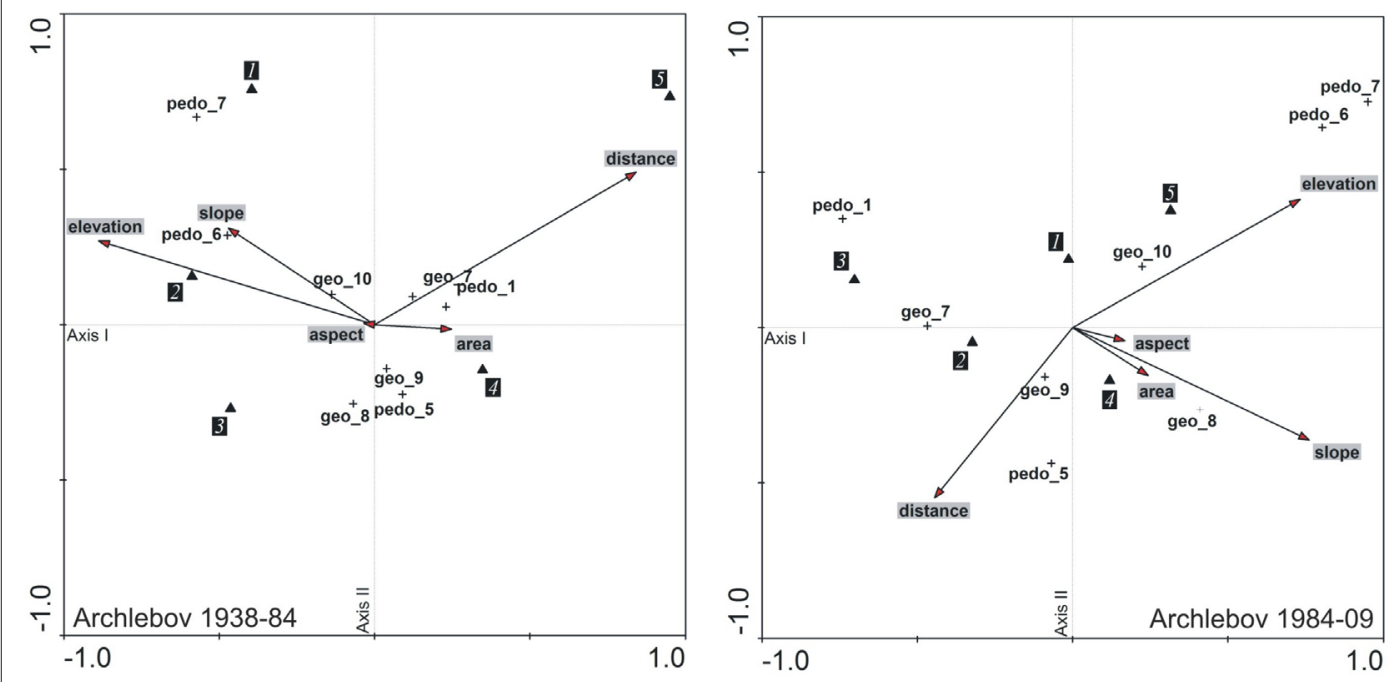

Fig. 4. CCA ordination of land cover transitions in two time periods (1938-1984 and 1984-2009) in the study area of Archlebov (for legend see Fig. 3 above)
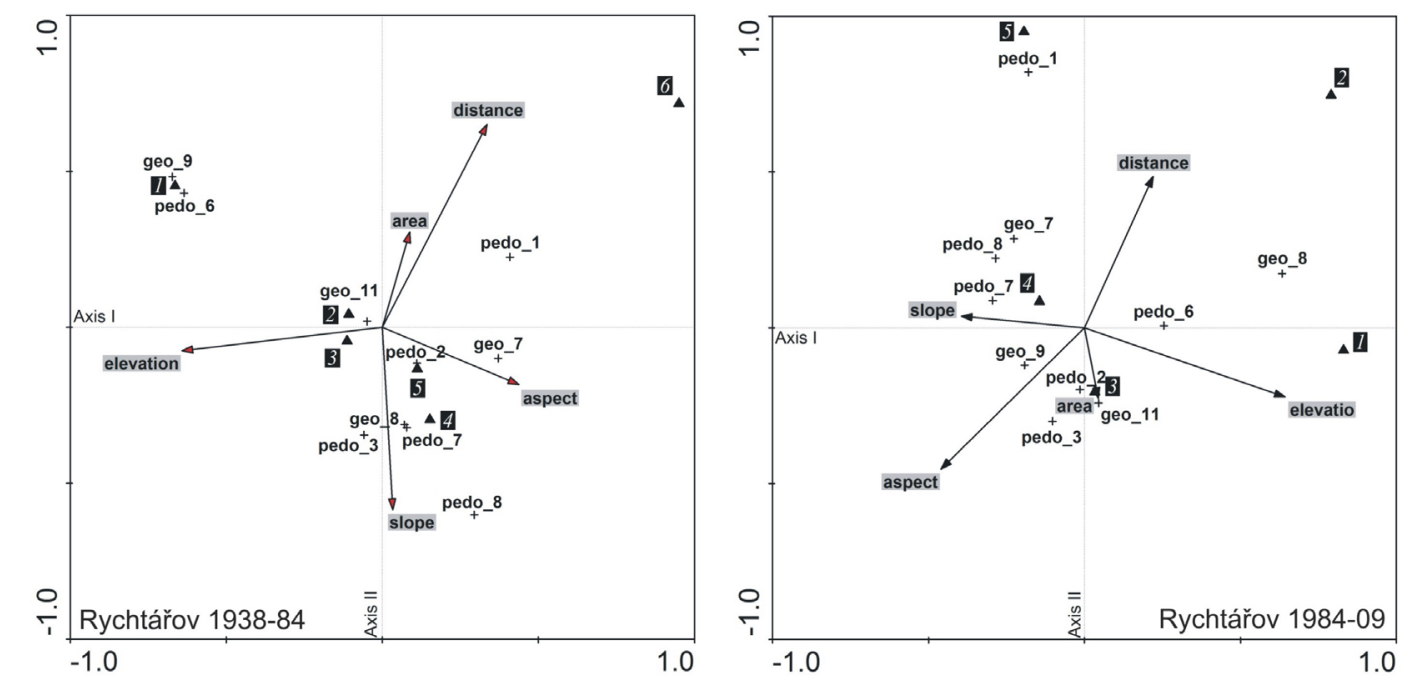

Fig. 5. CCA ordination of land cover transitions in two time periods (1938-1984 and 1984-2009) in the study area of Rychtár̆ov. Source: Statistical evaluation in Canoco for Windows, 2011

the majority of studies on the role of natural factors in the process of landscape changes (e.g Hietel et al, 2004; Huang et al., 2005); but, a certain inconsistency exists in the selection and classification of principal soil parameters (compare Hietel, 2005; Fu et al., 2006).

The use of CCA enables a correlational relationship to be specified between the environmental variables and the landscape changes. However, according to Hersperger (2010), this model cannot simply derive a causal connection from this proven correlation dependence. For a deeper knowledge of the nature of landscape changes the model must involve instigators of the change, too, e.g. local people, various institutions etc. (Burgi et al., 2004). Such an analysis can then allow identification and better understanding of the role of socio-economic factors which, due to their number and diversity, are very difficult for modelling with the use of the CCA analysis (Hietel, 2005).

\section{Conclusions}

The use of GIS methods combined with CCA enables the researcher to study the landscape change as a function of environmental factors at a local level, and to quantify the importance of natural factors in the process of landscape changes (Hietel et al., 2004). The CCA results showed the correlation of selected natural factors and landscape changes in the studied areas. The influence of slope gradient was the most significant in both intensification and extensification processes; altitude was also of notable influence. Other environmental and 
structural variables were represented less frequently as their importance varied according to the character of individual areas. Our research has confirmed the varying capacity of natural factors to explain the processes of landscape changes - the model achieved the greatest reliability in the area with the relatively low dynamics of landscape change and, at the same time, relatively high topographic diversity (Rychtářov). Highly dynamic landscape processes induced by significant political and consequential socio-economic changes reduced the role of natural factors in the process of landscape changes (Branná). The importance of environmental variables was also reduced by anthropogenic interventions (construction of agrarian terraces in the Archlebov area).

Although the statistical results of this study confirm physical constraints of land cover changes, only a limited proportion of landscape changes were dependent on natural factors. Therefore, basic driving forces behind land cover changes can be assumed to be socio-economic factors. Many various socio-economic driving forces such as regional planning, land tenure, income, political decisions and other factors can have an influence on land-cover changes in the study areas. However, the inclusion of socio-economic factors and their interaction with natural factors in CCA analysis is hampered by a number of barriers, and therefore remains challenge for a further research.

\section{Acknowledgement}

The authors of this article would like to thank for the support for their research, which was carried out with the help of NPV II $2 B 06101$ project entitled "Optimizing Agricultural and River Landscapes in CZ with Emphasis on the Development of Biodiversity" and AS CR Grant Agency KJB300860901 project "Quantitative and Synthesizing Graphic Methods in Approximation, Projection, and Modelling of Geographical Phenomena”.

\section{References}

BIČÍK, I., JELEČEK, L., ŠTĚPÁNEK, V. (2001): Land-use changes and their social driving forces in Czechia in the $19^{\text {th }}$ and $20^{\text {th }}$ century. Land Use Policy, Vol. 18, No. 1, p. 65-73.

BIČÍK, I., ŠTĚPÁNEK, V. (1994): Post-war changes of the land-use structure in Bohemia and Moravia: Case study Sudetenland. GeoJournal, Vol. 32, No. 3, p. 253-259.

BENDER, O. (2009): The concept of historic landscape analysis using GIS with a focus on Central Europe. In: Bender, O., Evelpidou, N., Krek, A., Vassilopoulos, A. [eds.]: Geoinformation Technologies for Geocultural Landscapes: European Perspectives. London, Taylor and Francis Group, p. 129-144.

BOSSARD, M., FERANEC, J., OŤAHEL, J. (2000): CORINE land cover technical guide - Addendum 2000. Technical report No. 40. Copenhagen, European Environment Agency, 105 pp.

BÜRGI, M., HERSPERGER, A. M., SCHNEEBERGER, N. (2004): Driving forces of landscape change - current and new directions. Landscape Ecology, Vol. 19, No. 8, p. 857-868.

CEBECAUEROVÁ, M. (2007): Analýza a hodnotenie zmien štruktůry krajiny (na príklade časti Borskej nížiny a Malých Karpát) : Analysis and assessment of changes in landscape structure (case study of selected area of Borská nížina lowland and the Malé Karpaty Mountains). Geographia Slovaca 24. Bratislava, Geografický ústav Slovenské akadémie vied, 136 pp.

CHEN, L., WANG, J., BOJIE, F., QIU, Y. (2001): Land-use change in a small catchment of northern Loess Plateau, China. Agriculture, Ecosystems and Environment, Vol. 86, No. 2, p. 163-172.

DEL BARRIO, G., ALVERA, B., PUIGDEFABREGAS, J., DIEZ, C. (1997): Response of high mountain landscape to topographic variables: Central Pyrenees. Landscape Ecology, Vol. 12, No. 2, p. 95-115.

DEMEK, J., HAVLÍČEK, M., CHRUDINA, Z., MACKOVČIN, P. (2008): Changes in land-use and the river network of the graben dyjsko-svratecký úval (Czech Republic) in the last 242 years. Journal of Landscape Ecology, Vol. 1, No. 2, p. $22-51$.

HIETEL, E., WALDHARDT, R., OTTE, A. (2005): Linking socio-economic factors, environment and land cover in the German Highlands, 1945-1999. Journal of Environmental Management, Vol. 75, No. 2., p. 133-143.

HIETEL, E., WALDHARDT, R., OTTE, A. (2004): Analysing land-cover changes in relation to environmental variables in Hesse, Germany. Landscape Ecology, Vol. 19, No. 5, p. 473-489.

FERANEC, J., OŤAHEL, J. (2001): Land Cover of Slovakia. Bratislava, Veda. 124 pp.

FERANEC, J., ŠÚRI, M., OŤAHEL, J., CEBECAUER, T., KOLÁŘ, J., SOUKUP, T., ZDEŇKOVÁ., D., WASZMUTH, J., VAAJDEA, V., VILDEA, A., NITICA, C. (2000): Inventory of major landscape changes in the Czech Republic, Hungary, Romania and Slovak Republic 1970s-1990s. International Journal of Applied Earth Observation and Geoinformation, Vol. 2, No. 2., p. 129-139.

FU, B. J., ZHANG, Q. J, CHEN, L. D., ZHAO, W. W., GULINCK, H., LIU, G. B., YANG, Q. Y., ZHU, Y. G. (2006): Temporal change in land use and its relationship to slope degrees and soil type in a small catchment on the Loess Plateau of China. Catena, Vol. 65, No. 1, p. 41-48. 
HERSPERGER, A. M., GENNAIO, M. P., VERBURG, P. H., BÜRGI, M. (2010): Linking land change with driving forces and actors: four conceptual models. Ecology and Society, Vol. 15, No. 4: [online] Available at: URL: http://www.ecologyandsociety. org/vol15/iss4/art1/.

HUANG, Q. H., CAI, Y. L., PENG, J. (2007): Modeling the spatial pattern of farmland using GIS and multiple logistic regression: a case study of Maotiao River Basin, Guizhou Province, China. Environmental Modelling Assessment, Vol. 12, No. 1, p. 55-61.

LIPSKÝ, Z. (1995): The changing face of the Czech rural landscape. Landscape and Urban Planning, Vol. 31, No. 1-3, p. 39-45.

Leica Geosystems (2006): Leica Photogrammetry Suite Project Manager. Norcross, Leica Geosystems Geospatial Imaging, $414 \mathrm{pp}$.

LOWICKY, D. (2008): Land use change in Poland during transformation. Case study of Wielkopolska region. Landscape and Urban Planning, Vol. 87, No. 4, p. 279-288.

LORINCZ, R., BALAZS, K. (2003): Historical land use analysis and landscape development investigations for devising sustainable land use structure. In: Mander, Ü., Antrop, M. [eds.]: Multifunctional Landscapes Volume III. Continuity and Change. Southhampton, Boston, WIT Press, pp. 243-261.

MACHAR, I., SERVUS, M. (2010): Linking historical research with restoration ecology in the floodplain landscape. Case study Tovačov Lakes, Czech Republic. Journal of Landscape Ecology, Vol. 3, No. 1, p. 16-41.

NĚMEČEK, J. [ed.] (2001): Taxonomický klasifikační systém půd České republiky. Praha, Česká zemědělská univerzita : Výzkumný ústav meliorací a ochrany půdy, 79 pp.

PAN, D., DOMON, G., DE BLOIS, S., BOUCHARD, A. (1999): Temporal (1958-1993) and spatial patterns of land use changes in Haut-Saint-Laurent (Quebec, Canada) and their relation to landscape physical attributes. Landscape Ecology, Vol. 14, No. 1, p. 35-52.

SCHNEIDER, L. C., PONTIUS, R. G. (2001): Modeling land-use change in the Ipswich watershed, Massachusetts, USA. Agriculture, Ecosystems and Environment, Vol. 85, No. 1, p. 83-94.

SIMPSON, J. W., BOERNER, R. E. J., DEMERS, M. N., BERNS, L. A., ARTIGAS, F. J., SILVA, A. (1994): Forty-eight years of landscape change on two contiguous Ohio landscapes. Landscape Ecology, Vol. 9, No. 4, p. 261-270.

ŠARAPATKA, B., ŠTĚRBA, O. (1998): Optimalization of agriculture in relation to the multifunctional role of the landscape. Landscape and Urban Planning, Vol. 41, No. 2, p. 145-148.

TER BRAAK, C. J. F., ŠMILAUER, P. (2002): CANOCO Reference Manual and CanoDraw for Windows User's Guide: Software for Canonical Community Ordination (version 4.5). 1 ed. Ithaca, Microcomputer Power, 500 pp.

VELDKAMP, A., LAMBIN, E. F. (2001): Predicting land-use change. Agriculture, Ecosystems \& Environment, Vol. 85, No. 1-3, p. 1-6.

\section{Author's adresses:}

Mgr. Zdeněk OPRŠAL, Ph.D., e-mail: zdenek.oprsal@upol.cz

Palacký University, Olomouc, Faculty of Science, Department of Development Studies

17. listopadu 12, Olomouc 771 46, Czech Republic

Prof. Ing. RNDr. Bořivoj ŠARAPATKA, CSc., e-mail: borivoj.sarapatka@upol.cz

Palacký University, Olomouc, Faculty of Science, Department of Ecology and Environmental Sciences

tř. Svobody 26, Olomouc 771 46, Czech Republic

Mgr. Petr KLADIVO, Ph.D., e-mail: petr.kladivo@upol.cz

Palacký University, Olomouc, Faculty of Science, Department of Geography

17. listopadu 12, Olomouc 771 46, Czech Republic

Initial submission 22 October 2012, final acceptance 27 February 2013

Please cite this article as:

OPRŠAL, Z., ŠARAPATKA, B., KLADIVO, P. (2013): Land-use Changes and their Relationships to Selected Landscape Parameters in three Cadastral Areas in Moravia (Czech Republic). Moravian Geographical Reports, Vol. 21, No. 1, p. 41-50. 